\title{
Kekerasan di Televisi: Perspektif Kultivasi
}

\author{
Dadi Ahmadi dan Nova Yohana
}

\begin{abstract}
Indonesians are categorized as Views Society, i.e. society who significantly spent most of their leisure times in front of the screen, instead of doing other activities, such as reading. Television, on the other hand, proved to be an effective media whose outreach and penetration potent were undefeatable compared with other media. This situation turns to be problematic, due to the low quality of television which contained violence materials. People naturally learn violence from television. Being overexposed to violence materials, people were getting used to solve their problems by means of violence, too.
\end{abstract}

Kata kunci: kekerasan, televisi, kultivasi

\section{Pendahuluan}

Munculnya media televisi dalam kehidupan manusia memang menghadirkan suatu peradaban, khususnya dalam proses komunikasi dan informasi yang bersifat massa. Globalisasi informasi dan komunikasi setiap media massa, jelas melahirkan satu efek sosial yang bermuatan perubahan nilainilai sosial dan budaya manusia. Televisi sebagai media yang muncul belakangan dibanding media cetak dan radio, ternyata memberikan nilai yang sangat spektakuler dalam sisi-sisi pergaulan hidup manusia saat ini. Daya tarik media televisi sedemikian besar, sehingga pola-pola rutinitas manusia sebelum muncul televisi, berubah total sama sekali. Media televisi menjadi panutan baru (news religius) bagi kehidupan manusia. Tidak menonton televisi, sama saja dengan makhluk buta yang hidup dalam tempurung.

Televisi merupakan salah satu media komunikasi massa dan mempunyai fungsi yaitu; memberi informasi, mendidik, menghibur, dan mempengaruhi (Onong, 1992). Menyampaikan berbagai infomasi kepada masyarakat adalah kewajiban bagi televisi yang memiliki fungsi mediasi. Tetapi, masalahnya, menurut pengamatan penulis, informasi yang disajikan bukan bersifat mendidik tetapi lebih banyak bersifat menghibur, bahkan menghancurkan masyarakat.

Menyaksikan tayangan televisi akhir-akhir ini, sungguh membuat hati miris. Hampir sepanjang waktu kita harus melihat kekerasan demi kekerasan berseliweran di layar kaca. Peristiwa demonstrasi yang berakhir dengan kerusuhan, perkelahian, dan pemukulan antarmahasiswa; perusakan yang berakhir dengan pembakaran, dan lain sebagainya, adalah menu yang selalu hadir lewat berbagai acara di televisi. Tayangan tersebut hadir lewat acara berita, sinetron, tayangan film, baik buatan dalam dan luar negeri. Dengan gencarnya tayangan kekerasan, timbul kekhawatiran akan terbentuknya sikap, karakter, dan tingkah laku masyarakat yang meniru apa yang disaksikan.

Sepatutnya kita merasa khawatir, jika kita mengamati fenomena meningkatnya kekerasan dalam menyelesaikan masalah akhir-akhir ini. Adakah kita berpikir dan sadar bahwa masyarakat telah belajar kekerasan melalui televisi? Bagi 
sebagian orang tentu saja menganggap bahwa pendapat ini terlalu berlebihan. Namun, bagi yang lain, potensi televisi sebagai pengajar dalam hal kekerasan adalah mungkin, bahkan sangat mungkin.

Alasan pertama bahwa masyarakat telah belajar kekerasan dari televisi adalah kenyataannya masyarakat Indonesia termasuk kategori Views Society yang artinya suatu keadaan di mana kegiatan menonton lebih ditonjolkan dibandingkan kegiatan lainnya, misalnya membaca.

Alasan kedua, bahwa dari hasil pengkajian televisi menunjukkan tingkat penetrasi televisi yang jauh lebih besar dibandingkan dengan media lain. Hal ini berarti bahwa media televisi memberikan imbas yang luar biasa bagi kehidupan masayarakat. Kehadirannya yang massif, langsung maupun tak langsung, akan berpengaruh pada perilaku dan pola pikir masyarakat.

Alasan ketiga, media massa secara pasti akan memengaruhi pemikiran dan tindakan khalayak penontonnya, bahkan budaya, sosial dan politik (Ardianto dan Ardinaya, 2007). Berdasarkan pendapat ini kita bisa menyatakan jika masyarakat menjadi keras, dan akhirnya menyelesaikan masalahnya dengan cara kekerasan pula akibat pengaruh dari media (dalam hal ini televisi).

Menurut pengamatan penulis, hampir secara terus menerus, televisi menayangkan acara dengan muatan kekerasan, sehingga masyarakat memperoleh satu pembelajaran yang pasti bahwa untuk menyelesaikan masalah, jalan yang harus mereka tempuh adalah melalui kekerasan.

Berdasarkan fenomena tersebut, maka fokus kajian dalam makalah ini adalah melihat sejauh mana tayangan kekerasan menghiasi media televisi dan dampaknya bagi perilaku masyarakat dengan pendekatan analisis kultivasi.

\section{Teori Kultivasi}

Teori kultivasi (cultivation theory) dikembangkan untuk menjelaskan dampak menyaksikan televisi pada persepsi, sikap, dan nilai-nilai individu. Teori ini berasal dari program riset jangka panjang dan ekstensif, yang dilakukan George Gerbner beserta para koleganya, di
Annenberg School of Communication di University of Pennsylvania (Gerbner, Gross, Morgan, dan Signorielli, 1980 dalam Tankard 2005: 319). Gerbner beserta para koleganya mulai dengan argumentasi bahwa televisi telah menjadi tangan budaya utama masyarakat Amerika. "Televisi telah menjadi anggota keluarga yang penting, anggota yang bercerita paling banyak dan paling sering." Rata-rata pemirsa menonton televisi empat jam sehari. Pemirsa "berat" bahkan menonton lebih lama lagi.

Tim Gerbner menyatakan bahwa bagi pemirsa "berat", televisi pada hakikatnya memonopoli dan memasukkan sumber-sumber informasi, gagasan, dan kesadaran lain. Dampak dari semua keterbukaan ke pesan-pesan yang sama menghasilkan apa yang oleh para peneliti disebut Kultivasi, atau pengajaran pandangan bersama tentang dunia sekitar, peran-peran bersama, dan nilai-nilai bersama.

Menurut Signorielli dan Morgan (1990 dalam Griffin, 2004), analisis kultivasi merupakan tahap lanjutan dari paradigma penelitian tentang efek media, yang sebelumnya dilakukan George Gerbner, yaitu 'cultural indicator' yang menyelidiki: (a) proses institusional dalam produksi isi media, (b) image (kesan) isi media; dan (c) hubungan antara terpaan pesan televisi dengan keyakinan dan perilaku khalayak. Dapat dikatakan penelitian kultivasi yang dilakukannya lebih menekankan pada dampak/efek. Analisis kultivasi adalah satu bagian dari program penelitian yang berkesinambungan, terus menerus yang dilakukan dalam jangka panjang.

Melalui Cultivation Analysis, Gerbner bersama beberapa rekannya kemudian melanjutkan penelitian media massa tersebut dengan memokuskan pada dampak media massa dalam kehidupan sehari-hari. Dari analisis tersebut diperoleh berbagai temuan yang menarik dan orisinal, yang kemudian banyak mengubah keyakinan orang tentang relasi antara televisi dan khalayaknya berikut berbagai efek yang menyertainya. Karena konteks penelitian ini dilakukan dalam kaitan merebaknya acara kekerasan di televisi dan meningkatnya angka 
kejahatan di masyarakat, maka temuan penelitian ini lebih terkait efek kekerasan di media televisi terhadap persepsi khalayaknya tentang dunia tempat mereka tinggal.

Salah satu temuan terpenting adalah bahwa penonton televisi dalam kategori berat (heavy viewers) mengembangkan keyakinan yang berlebihan tentang dunia sebagai tempat yang berbahaya dan menakutkan. Sementara, kekerasan yang mereka saksikan di televisi menanamkan ketakutan sosial (sosial paranoia) yang membangkitkan pandangan bahwa lingkungan mereka tidak aman dan tidak ada orang yang dapat dipercaya. Gerbner berpendapat bahwa media massa menanamkan sikap dan nilai tertentu. Media pun kemudian memelihara dan menyebarkan sikap dan nilai tersebut antaranggota masyarakat, kemudian mengikatnya bersama-sama pula. Media memengaruhi penonton dan masing-masing penonton itu menyakininya. Jadi, para pecandu televisi itu akan punya kecenderungan sikap yang sama satu sama lain.

Menurut perspektif kultivasi, televisi menjadi media utama di mana para penontonnya belajar tentang masyarakat dan kultur di lingkungannya. Dengan kata lain, persepsi apa yang terbangun di benak kita tentang masyarakat dan budaya, sangat ditentukan oleh televisi. Artinya, melalui kontak kita dengan televisi, kita belajar tentang dunia, orang-orangnya, nilai-nilainya, dan adat istiadatnya. Perspektif kultivasi pada awal perkembangannya lebih memokuskan kajian pada studi televisi dan khalayak. Fokus utamanya pada tema-tema kekerasan di televisi. Tiga konsep penting (yang dimodifikasi dalam pelbagai varian) kekerasan di televisi, digunakan dalam penelitian-penelitian media efek, yaitu:

1. Media Violence, atau kekerasan di media. Yang dimaksud adalah isi media yang mengandung unsur kekerasan. Bisa berupa unsur kekerasan yang terdapat dalam film, televisi, berita. dll. Pada level individu, yang diteliti adalah terpaan isi media yang mengandung kekerasan pada individu.

2. Violence didefinisikan Gerbner (1972) sebagai 'the overt expression of physical force against others or self, or the commpelling action against one's will on pain of being hurt orkilled."

3. Aggressive Behavior, didefinisikan Berelson (1973) sebagai "inflicting bodily harm to other and damage to property."

Teori kultivasi melihat media massa sebagai agenda sosialisasi, dan menemukan bahwa penonton televisi dapat mempercayai apa yang ditampilkan oleh televisi berdasarkan seberapa banyak mereka menontonnya (www.asudayton/ edu/com/faculty/kenny/cultivation.html).

Berdasarkan banyaknya waktu yang dihabiskan untuk menonton, maka penonton televisi dikelompokkan dalam dua kategori, yakni light viewer (penonton ringan dalam arti menonton rata-rata dua jam perhari atau kurang dan hanya tayangan tertentu) dan heavy viewer (penonton berat), menonton rata-rata empat jam perhari atau lebih dan tidak hanya tayangan tertentu (Infante, et.al, 2003).

Secara keilmuan, untuk menunjukan bahwa televisi sebagai media yang memengaruhi pandangan kita terhadap realitas sosial, para peneliti cultivation analysis bergantung kepada dua jenis analisis: analisis pertama yakni analisis isi (content analysis), yang mengidentifikasikan atau menentukan tema-tema utama yang disajikan oleh televisi. Analisis kedua adalah Analisis khalayak (audience research), yang mencoba melihat pengaruh tema-tema tersebut pada penonton. (www.aber.uk/media/documents/short/ cultiv.html)

Teori kultivasi sering digunakan untuk menganalisis berbagai bentuk praktik komunikasi, terutama komunikasi massa, khususnya televisi apa yang kita kenal cultivation analysis. George Gerbner (1972) melakukan studi analisis isi dan menemukan bahwa acara TV yang diputar pada jam-jam utama (prime time) berisi 8 contoh kekerasan setiap jamnya. Televisi, sebagaimana diteliti oleh Garbner, dianggap sebagai pendominasi "lingkungan simbolik" seseorang. Teori kultivasi menganggap bahwa televisi tidak hanya disebut sebagai jendela atau refleksi kejadian sehari-hari disekitar kita, tetapi dunia itu 
sendiri (McQuail dan Windahl, 1993). Garbner juga berpendapat bahwa gambaran adegan kekerasan di televisi lebih merupakan pesan simbolik tentang hukum dan aturan. Dengan kata lain, perilaku kekerasan yang diperlihatkan di televisi merupakan refleksi kejadian di sekitar kita. Jika adegan kekerasan itu merefleksikan aturan hukum yang tidak bisa mengatasi situasi seperti yang digambarkan dalam adegan televisi, bisa jadi yang terjadi sebenarnya juga begitu.

\section{Hasil Analisis Kultivasi Tayangan Kekerasan dalam Media Televisi}

\subsection{Dampak Tayangan Kekerasan Televisi dari Beberapa Hasil Penelitian}

Menurut berbagai studi, tayangan televisi terbukti mempunyai pengaruh kuat. Dengan melihat, orang menjadi lebih percaya. Apa yang tampak di televisi dianggap sebagai realitas bermakna. McLuhan, seorang ahli psikologi komunikasi berpendapat bahwa manusia berhubungan dengan televisi sudah tidak hanya melihat atau menonton lagi, tapi sudah terlibat di dalamnya. Apalagi dengan kemajuan tehnologi sekarang ini.

Di antara penelitian yang dilakukan untuk mengetahui efek terpaan media televisi pada khalayak, adalah efek media violence. Salah satunya yang dilakukan oleh Huesmann \& Eron (1986). Mereka meneliti anak-anak yang diterpa siaran televisi sejak usia 8 tahun sampai 30 tahun. Metode yang digunakan, yaitu panel survei, dan ternyata diperoleh hasil bahwa mereka yang menonton acara kekerasan di TV pada level tertinggi saat anak-anak lebih cenderung terlibat kejahatan serius ketika dewasa. Zillman (1991) mengemukakan teori exitation transfer yang memperkenalkan properti arousal inducing pada media violence untuk memahami intensitas reaksi emosional setelah menonton. Hasilnya, seorang penonton bangkit rasa marahnya setelah diterpa media violence. Arousal atau bangkitnya rasa marah, ini dapat ditransfer pada kemarahan yang sesungguhnya, bahkan mengintensifkan hingga menambah kecenderungan berperilaku agresif.

Nancy Signorielli (Littlejohn, 1996) melaporkan studi tentang sindrom dunia kejam. Pada aksi kekerasan di program televisi bagi anak, lebih dari 2000 program, termasuk 6000 karakter utama selama prime time dan akhir pekan (weekend) dari tahun 1967-1985, menganalisis dengan hasil yang menarik, 70\% prime time dan 94\% akhir pekan (weekend) termasuk aksi kekerasan. Analisis ini membuktikan heavy viewers memandang dunia muram dan kejam dibandingkan dengan orang yang jarang menonton televisi. Tidak salah jika kemudian Gerbner dan kawan-kawan melaporkan bahwa heavy viewers melihat dunia lebih kejam dan menakutkan seperti yang ditampilkan televisi dari pada orang-orang yang jarang menonton.

Gerbner melakukan penelitian dampak televisi dengan menggunakan metode survey analisis, di mana populasi dan sample adalah penonton pria dan wanita yang dibedakan berdasar usia, yaitu; dewasa, remaja, dan anak-anak. Juga diperoleh data bahwa rata-rata orang menonton TV di Amerika Serikat adalah 7 jam sehari. Maka, muncul istilah heavy viewers (pecandu berat televisi) dan light viewers atau viewers (penonton biasa). Para pecandu berat televisi akan menganggap bahwa apa yang terjadi di televisi itulah dunia senyatanya. Misalnya, menanggapi perilaku kekerasan yang terjadi di masyarakat. Para pecandu berat televisi akan mengatakan bahwa sebab utama munculnya kekerasan karena masalah sosial (karena televisi yang sering ia tonton sering menyuguhkan berita dan kejadian dengan motif kekerasan). Padahal, bisa jadi sebab utama itu lebih karena faktor $\mathrm{cul}$ tural shock dari tradisional ke modern. Contoh lainnya, yaitu pecandu berat televisi mengatakan bahwa 20\% penduduk dunia berdiam di Amerika, padahal senyatanya cuma $6 \%$. Dengan kata lain, penilaian, persepsi, opini penonton televisi, digiring sedemikian rupa agar sesuai dengan apa yang mereka lihat di televisi. Bagi pecandu berat televisi, apa yang terjadi pada televisi itulah yang terjadi pada dunia sesungguhnya. Gerbner berpendapat bahwa media massa menanamkan sikap dan nilai tertentu. Media memengaruhi 
penonton dan masing-masing penonton meyakininya. Dengan kata lain, pecandu berat televisi mempunyai kecenderungan sikap yang sama satu dengan lainnya.

Televisi, sebagaimana diteliti Garbner, dianggap sebagai pendominasi "lingkungan simbolik" seseorang. Teori kultivasi menganggap bahwa televisi tidak hanya disebut sebagai jendela atau refleksi kejadian sehari-hari di sekitar kita, tetapi dunia itu sendiri (McQuail dan Windahl, 1993). Garbner juga berpendapat bahwa gambaran adegan kekerasan di televisi lebih merupakan pesan simbolik tentang hukum dan aturan. Dengan kata lain, perilaku kekerasan yang diperlihatkan di televisi merupakan refleksi kejadian di sekitar kita. Jika adegan kekerasan itu merefleksikan aturan hukum yang tidak bisa mengatasi situasi seperti yang digambarkan dalam adegan televisi, bisa jadi yang terjadi sebenarnya juga begitu.

Perilaku imitatif atau peniru sangat menonjol pada anak-anak. Permasalahan ini diperparah oleh kemampuan berpikir anak masih relatif sederhana. Mereka cenderung menganggap apa yang ditampilkan televisi sesuai dengan yang sebenarnya. Mereka masih sulit membedakan mana tayangan yang fiktif yang nyata. Anak juga masih sulit membedakan perilaku yang baik sesuai dengan norma etika, agama, dan hukum.

Menurut Aletha Huston, dari University of Kansas, anak-anak yang menonton kekerasan di TV lebih mudah dan lebih sering memukul temantemannya, tak mematuhi aturan kelas, membiarkan tugasnya tidak selesai, dan lebih tidak sabar dibandingkan dengan anak yang tidak menonton kekerasan di TV. Di Amerika Serikat, terdapat sekitar 3.000 studi yang telah dilakukan oleh berbagai kalangan intelektual dan peneliti untuk menjelaskan pengaruh media terhadap tindak kekerasan dan perilaku berutal seperti itu yang terjadi di kalangan remaja. Dari jumlah tersebut, terdapat dua studi yang cukup menarik dikaji lebih lanjut, yakni studi yang dilakukan oleh UCLA Television Violance Monitoring Report dan Mediascope, Inc, yang telah disponsori National Cable Television Association. Studi itu menunjukkan, 23\% film cartoon menyajikan berbagai bentuk kekerasan. Sekitar 30\% dari 73\% film kekerasan yang ditayangkan di TV, memperlihatkan penggunaan untuk membunuh dan menyiksa lawannya. Kekejaman seperti telah dengan sendirinya mewarnai alam pikiran pemirsa yang masih belum dewasa itu.

Temuan lain dari studi itu menunjukkan bahwa anak yang banyak menyaksikan film- film keras cenderung berperilaku agresif, mudah menentang aturan-aturan yang ada. Dari sekitar 800 anak yang berusia sekitar 8 tahun yang dijadikan sampel cenderung berperilaku amat agresif di kelas atau di lingkungannya. Perilaku kekerasan itu yang dibentuk oleh media, ternyata tidak hanya memengaruhi kalangan anak yang berlatarbelakang sosial-ekonomi tinggi, tetapi juga dari mereka kelas menengah dan rendah. Artinya, pengaruh media terhadap perilaku kekerasan tidak membedakan jenis kelamin, latar belakang ekonomi, sosial dan budaya seseorang.

Beberapa ahli menunjukkan adanya potensi imitasi atau peniruan sebagai efek segera yang sering muncul di masyarakat atas tayangan kekerasan di televisi. Adapun efek jangka panjang adalah habituation, yaitu orang menjadi terbiasa dengan kekerasan dan kriminal. Akibatnya, orang menjadi tidak peka, permisif, dan toleran terhadap kekerasan. Bahkan, Porter (1999) menunjuk adanya learning social norms karena tayangan kekerasan yang terus-menerus, bisa dianggap cara yang dibenarkan untuk menyelesaikan masalah. (http:// www.kompas.com/kompas-cetak/0406/04/opini/ 1060114.htm)

Dari beberapa penelitian tersebut, bisa dibayangkan dampak yang akan terjadi di masyarakat Indonesia jika acara yang ditonton sebagian besar tentang kekerasan. Maka, tak heran bila masyarakat Indonesia "makin akrab" terhadap berbagai bentuk kekerasan. Terlebih bila objeknya tersangka pelaku kriminal. Untuk mereka, dihajar, ditembak, dibunuh, bahkan dibakar hidup-hidup, seakan sudah dianggap "wajar". Hukum dan prasangka baik sering tidak berlaku bagi tersangka kriminal. Apalagi mempertimbangkan mereka mungkin korban keadaan. Keadaan ekonomi dan sosial sering mengondisikan orang-orang tertentu 
berbuat jahat. Namun, pemikiran demikian tenggelam dengan "dipupuknya" budaya kekerasan oleh media, yang secara tak langsung menyosialisasikan cara berpikir pendek dan tidak mencerahkan.

Walaupun banyak ahli mengatakan bahwa khalayak selektif terhadap pesan dari media massa (televisi), juga faktor pendidikan, budaya, dan lingkungan tempat tinggal lebih berpengaruh daripada tayangan televisi, tetapi jika kita kaitkan dengan situasi di Indonesia yang sebagian besar penduduknya hidup di daerah terpencil, pendidikan masih rendah, kontrol sosial yang kecil, maka sepertinya dampak negatif yang akan lebih berpengaruh daripada dampak positifnya.

Stuart Hall, kulturalis media, menyusun kategori khalayak media dalam tiga klasifikasi: dominant reader, oppositional reader, dan negotiated reader. Dominant reader adalah kategori khalayak yang mengikuti arus dominan pemberitaan media - apa pun kata media dikunyah habis-habisan, tanpa kecuali. Oppositional reader, sebaliknya, kategori khalayak yang selalu bertentangan sikap dengan arus dominan media. Media jadi sejenis public enemy yang banyak menghasut masyarakat untuk mengganti nilai-nilai luhur dengan nilai-nilai "modern" dan "kosmopolitan". Kategori negotiated reader merujuk khalayak media yang moderat. Bila yang ditampilkan media sesuai dengan keyakinannya, mereka akan memanfaatkan media. Namun, ketika bertentangan, media akan ditinggalkan. Jenis khalayak terakhir bersikap kritis dalam menyikapi media.

Sayangnya, sebagian penonton televisi kita agaknya tergolong kategori dominant reader. Mereka mengikuti, saja arus media, mengunyah apa pun yang ditampilkan media massa, dan mengonsumsi segala konflik-peristiwa yang disuapkan media. (Astuti, 2005). Efek kultivasi semakin lengkap ketika media berhadapan dengan khalayak penonton yang pasif. Khalayak dominant reader percaya saja dengan apa pun yang ditampilkan media. Mereka tidak menyikapinya dengan kritis. Mereka tidak membandingkannya dengan sumber-sumber informasi kredibel lain.

\subsection{Kategorisasi tayangan kekerasan dalam Media Televisi}

Berdasarkan perspektif kultivasi mengenai kekerasan dalam media televisi, penulis mengkategorisasikan bentuk-bentuk tayangan kekerasan dalam televisi.

\subsubsection{Tayangan Kekerasan dalam Bentuk Berita Kriminal}

Tayangan kriminalitas dan kekerasan sudah menjadi menu harian televisi. Tak kurang dari 8 program televisi bertema kriminalitas dengan berbagai nama program ditayangkan setiap hari oleh stasiun-stasiun televisi di Indonesia, dengan durasi sedikitnya 30 menit hingga 1 jam. Sekadar contoh, kita bisa menyebut "Sergap" (RCTI), "Buser" (SCTV), "Patroli" (Indosiar), "Sidik”(TPI), "Kriminal" (Trans TV), "Tajuk Kriminal" (TV7), atau "Sidik Jari" (ANTV). Ini dalam berita-berita berdurasi pendek. Dalam durasi panjang, kodekode kekerasan berloncatan, antara lain dari "Derap Hukum" (SCTV), "Fakta" (ANTV), "Investigasi" (Lativi), "Cedera" (TPI), atau "Jejak Kasus" (Indosiar). Ini belum termasuk berita-berita kriminalitas dalam program liputan umum.

Dilihat dari jam tayangnya, sebagian besar program kriminalitas menempati jam-jam prime time, yaitu rentang waktu di mana jumlah penonton televisi mencapai puncaknya. Kenyataan ini dikuatkan dengan laporan rating program televisi yang memperlihatkan bahwa tayangan bertema kriminalitas, di samping infotainment dan tayangan bertema klenik-supranatural, menjadi primadona dengan menempati ranking-ranking teratas program yang paling banyak ditonton khalayak.

Suatu hari, pada acara berita kriminal yang penulis saksikan di televisi swasta, muncul adegan polisi membawa pistol mengejar seorang tersangka pencuri sepeda motor. Tiba-tiba terdengar suara tembakan berkali-kali dan bentakan-bentakan. Lalu, tampak seorang pemuda berlumuran darah diseret petugas.Kamera meng-close up wajah "tersangka penjahat" yang badannya penuh tato, menggelesot di tanah dengan mimik merintih. Narasi berita menyebutkan, polisi terpaksa 
menembak karena si tersangka berusaha melarikan diri.

Berikutnya, disajikan berita kasus pemerkosaan. Pelakunya remaja. Kamera memperlihatkan rumah yang sedang dikepung petugas. Lalu pintu didobrak, petugas masuk, dan si pelaku ditangkap. Tak jelas apa yang terjadi saat ditangkap. Yang jelas, wajah pelaku sudah bengap. Artinya, gambar itu bercerita bahwa pelaku sudah dipukuli sebelum ditangkap. Ada lagi adegan sebuah rumah digerebek beberapa polisi. Seorang ibu berteriak-teriak karena anaknya yang berambut gondrong itu dijambak dan diseret petugas reserse antinarkoba. Narator berita menyebutkan, pemuda itu merupakan target operasi antinarkoba, ditangkap beserta barang bukti. Adegan kekerasan, penganiayaan, atau gambar korban yang mengerikan, tiap hari bisa disaksikan di hampir seluruh stasiun televisi swasta. Pelakunya beragam. Kadang penjahat, kadang warga masyarakat, dan tak jarang polisi. Peristiwanya sendiri ada yang direkam saat peristiwa terjadi, ada pula yang reka ulang dan adegannya mirip film laga, serta ada yang seperti sandiwara. Pada reka ulang semacam itu, belum tentu sesuai dengan peristiwanya dan sebenarnya dilarang oleh UUNo. $32 / 2002$ tentang penyiaran. Apalagi bila yang ditayangkan tersebut belum jelas status hukumnya melalui putusan tetap yang dikeluarkan oleh pengadilan.

Dalam perspektif kultivasi, adegan yang terjadi dalam acara-acara itu menggambarkan dunia kita yang sebenarnya. Bahwa di Indonesia kejahatan itu sudah demikian luas dan mewabah. Acara itu menggambarkan dunia kejahatan yang sebenarnya yang ada di Indonesia (Nurudin, 2003). Tuduhan munculnya kejahatan di dalam masyarakat disebut dengan "sindrom dunia makna". Pecandu berat televisi memandang dunia sebagai tempat yang buruk, tidak demikian dengan pandangan pecandu ringan. Efek kultivasi memberikan kesan bahwa televisi mempunyai dampak yang sangat kuat pada diri individu. Mereka beranggapan bahwa lingkungan sekitarnya sama seperti yang tergambar di televisi.

Mencermati fenomena ini, jelas bahwa kondisi industri pertelevisian di Indonesia sendiri telah menyuburkan situasi yang memungkinkan masyarakat diterpa informasi kriminalitas tanpa henti, sehingga memperbesar kemungkinan berlakunya efek media pada masyarakat. Penayangan visual penuh kekerasan dan kesadisan di televisi akan sangat mempengaruhi perilaku pemirsanya, terutama anak-anak yang belum dapat memilah mana yang baik, mana yang buruk. Masih terasa hiruk pikuk pro-kontra dampak adegan kekerasan di televisi kita tahun 2006. Bahkan, acara seperti smack down yang disiarkan sebuah televisi swasta di Indonesia menelan korban atas tewasnya Resa Ikhzan Fadillah (9), siswa SDN Cingcin. Ini belum termasuk yang berdampak patah tulang pada anak-anak, luka berat dan semacamnya.

Kejadian tersebut mengingatkan kita akan dampak acara televisi terhadap perilaku kekerasan pada anak-anak. Menurut teori kultivasi ini, persepsi apa yang terbangun di benak anak-anak tentang masyarakat dan budaya sangat ditentukan oleh televisi. Ini artinya, melalui kontak anak-anak dengan televisi, anak-anak belajar tentang dunia, orang-orangnya, nilai-nilainya, serta adat kebiasannya. Televisi karenanya, mampu menanamkan sikap dan nilai tertentu pada diri anakanak itu. Dengan demikian, anak-anak dengan adanya tayangan kekerasan di televisi akan menganggap bahwa kekerasan itulah yang sedang terjadi di tengah masyarakat. Jadi, anak-anak akan menganggap perilaku kekerasan yang dilakukannya hal biasa saja. Apalagi anak-anak dalam proses pertumbuhannya sedang dalam taraf meniru.

Acara seperti "Sergap", "Patroli”, "Buser", dan berbagai acara senada lainnya, memang memberi sedikit pelajaran kepada masyarakat untuk berhati-hati dan selalu waspada. Namun, ketika acara-acara tersebut mengeksploitasi perilaku kekerasan secara vulgar, dengan mempertontonkan orang-orang yang bersimbah darah, reka ulang tindak kejahatan, dan tindakan aparat terhadap para pelaku kriminal yang kasar serta terkadang tidak berperikemanusiaan, membuat pesan moral yang ingin disampaikan 
menjadi sia-sia.

Meski mungkin tujuannya memberikan informasi, namun cara penyajiannya banyak yang melanggar etika, bahkan UU Penyiaran.

\subsubsection{Tayangan Kekerasan dalam Bentuk Film dan Sinetron}

Fenomena audio-visual sekarang yang berorientasi sinetron, sudah sedemikian naifnya. Moral dituntun ke arah yang negatifkalau kita tidak bisa menangkap hikmahnya. Lihat, misalnya, dalam tayangan sinetron, masih SMP dan SMA sudah menggunjingkan pacaran dan problemanya, dan karena kecemburuan terjadilah kekerasan.

Berbeda dengan eksploitasi pada tayangan berita, di sinetron kekerasan dalam rumah tangga juga cenderung tinggi. "Yang muncul dalam benak penonton, relasi dalam keluarga mirip dalam tayangan sinetron. Saling menyiksa antaranggota keluarga, bahkan secara verbal pun seakan memperbolehkan saling mencaci dan menghina. Sebut saja, misalnya, sinetron "Candy" yang diputar di RCTI tiga kali sepekan, pukul 19.00, bisa dijadikan contoh. Aksi dorong sudah menjadi adegan biasa saja, tidak dianggap sebagai bentuk kekerasan atau intimidasi. Dalam kisah itu, Candy adalah anak panti asuhan yang kemudian diambil anak oleh satu keluarga. Namun, ternyata dijadikan pembantu. Belum lagi sinetron lainnya seperti "Azizah", "Bawang Merah-Bawang Putih" dan "Monyet Cantik". Meskipun terkadang diselipkan pesan-pesan moral, namun porsinya sangat sedikit jika dibandingkan dengan tayangan kekerasan yang mendominasi setiap episode sinetron tersebut. Bahkan, sinetron-sinetron yang bertema agama pun tak luput dari tayangan kekerasan, seperti yang terlihat pada sinetron "Ramadhan Shaleha", “Aisyah", "Sujudku”. Termasuk juga merambah segmen berita yang bertajuk kriminal dan hukum.

Selain tayangan kekerasan di sinetron, dalam sejumlah film juga ditayangkan tindak kekerasan. Selama ini, orang selalu beranggapan, tindak kekerasan dalam sejumlah film yang ditayangkan oleh berbagai siaran televisi di negeri ini hanya terdapat dalam film-film dewasa yang marak dengan adegan pukul-pukulan, banting-bantingan, bentak-bentakan, dan bunuh-bunuhan, yang dibumbui adegan seks. Padahal, kalau dicermati secara sungguh-sungguh, apa yang dinamakan tindak kekerasan itu marak juga dalam tayangan film-film kartun, seperti Tom \& Jerry, Doraemon, P-Man, Crayon Shinchan, serta filmfilm kartun lainnya, baik yang diproduksi oleh perusahaan film kartun Jepang maupun Amerika. Film Tom \& Jerry contohnya. Tak bisa diingkari penuh dengan imajinasi, banyak sekali ide cerdas serta mengagumkan yang dimunculkan, baik oleh Jerry, yang suka usil, dan Tom (yang kerap berprilaku jahat), tapi demi mencapai tujuannya Tom dan Jerry tak jarang melakukan tindakan subversif, seperti memukul, membanting, membentak, mencelakakan, bahkan berupaya membunuh seperti biasanya yang ada dalam dewasa

Begitu halnya dengan film kartun SpongeBob, yang menurut pengamatan termasuk kategori film kartun berbahaya. Figur-figur di film kartun ini memang memiliki nilai-nilai perkawanan yang solid, tapi mereka juga sering melakukan praktik kekerasan dan percakapan yang tak enak didengar telinga, terutama telinga anak-anak. Dengan kemampuan nalarnya yang terbatas dalam menyerap serta mencerna makna yang ditayangkan oleh televisi, bukan suatu yang mustahil apa yang dilakukan Tom dan Jerry serta figur dalam SpongeBob dianggap perbuatan yang sah-sah saja oleh anak-anak.

Tak menutup kemungkinan, karena dilakukan dengan lucu, maka anak justru tertawa saat figur dalam film kartun tadi mempraktikkan tindak kekerasan, baik secara fisik maupun psikis (mengejek, menghardik, dll). Ini artinya anak juga akan menganggap wajar (bahkan dianggap lucu) saat anak menendang temannya, atau bermusuhan dengan temannya sepanjang seperti yang dicontohkan Tom dan Jerry dalam Tom \& Jerry. Bukankah anak-anak adalah peniru ulung, dalam hal ini sesuatu yang ditampilkan oleh film kartun tadi. Jika setiap waktu anak-anak menonton dengan kualitas mengerikan, dapat dibayangkan 
seperti apa jeleknya perilaku mereka.

\subsubsection{Tayangan Kekerasan dalam Bentuk Iklan}

Tidak hanya berita kriminal, film, atau sinetron, tayangan iklan di televisi juga mengandung unsur kekerasan bila dicermati. Sebagai contoh, Yamaha dengan iklannya mereprentasikan kebandelan sebagai kekerasan. Efeknya adalah kehancuran bagi pihak lain. Kekerasan atau pun keonaran divisualisasikan dengan jelas, berulang-ulang, dan menjadi bagian dari kesenangan. Tak ada yang lebih mencintai "kebandelan" selain Yamaha. Bahkan, "persepsi" kebandelan itu terus diperbarui menjadi keonaran dan kebrutalan. Lihatlah iklannya, Awalnya, Komeng, hanya zig-zag di jalan raya, menyalip siapa saja, cepat, dan sampai tujuan dengan baju compang-camping. Atau memboncengkan Tessa Kaunang, dengan hasil rambut yang jadi awutawutan. Selanjutnya, efek "kebandelan" Yamaha dipertegas. Mulai mengacaukan roda delman, merubuhkan pot-pot bunga, sampai merusak kacamata. Korbannya selalu Didi Petet, dan pencetus kagum Dedy Mizwar. Terakhir, efek itu dipertegas dengan "super-duper" hiperbolis, meruntuhkan jembatan Kalibeber, dan terakhir merontokkan motor lain, sampai hanya layak jadi rongsokan.

Kini, keonaran dan kehancuran itu juga punya pengikut. Iklan minuman Tebs, contohnya. Versi terbaru iklan teh bersoda ini menampilkan keonaran akibat "kejutan rasa" Tebs. Rekaman video di kantor polisi menunjukkan bagaimana dahsyatnya dampak tegukan Tebs; mobil bertubrukan, pedagang dengan jualan yang berhamburan, orang-orang yang panik. Selanjutnya adalah rasa bangga penenggaknya. Itulah iklan yang secara bagus mampu membahasakan kenikmatan sebagai kehancuran bagi orang lain.

Selain iklan tersebut, iklan yang berbau porno pun turut memengaruhi tindak kriminalitas. Iklan kondom yang ditayangkan di media massa, bahkan hanya ditayangkan di MTV, yang dikenal sebagai TV-nya anak muda, memberikan pengaruh yang signifikan dalam mendorong anak muda untuk melakukan seks bebas. Iklan kondom itu seolah- olah menjustifikasi bahwa seks bebas itu diperbolehkan, asal memakai kondom. Karena, seperti yang dikatakan dalam teori kultivasi, semakin terekspos seseorang dengan terpaan media massa, maka semakin dia mempercayai realitas media massa sebagai realitas yang real. Oleh karena itu, sebaiknya iklan kondom tidak ditayangkan di TV anak muda, atau bahkan tidak usah sama sekali, agar tidak berkontribusi dalam degradasi moral yang terjadi pada anak muda bangsa.

\section{Penutup}

Dulu, adegan kekerasan hanya bumbu sebuah tayangan atau berita. Kini, ketika pertelevisian bersaing ketat, kekerasan dan kriminalitas menjadi menu favorit yang dikemas, dijual, dan diberi acara tersendiri. Selama rating-nya tinggi, pengelola televisi seakan merasa "sah" menayangkan kekerasan dan kriminal. "Seing is believing".

Efek kriminalitas di televisi, tetap saja perlu diwaspadai ketika muncul dalam bentuk desensitisasi kekerasan. Desensitisasi kekerasan, atau penumpulan kepekaan terhadap kekerasan merupakan gejala yang umum terjadi ketika kekerasan tak lagi dianggap sebagai hal yang luar biasa. Maka, tatkala masyarakat diterpa oleh informasi kekerasan, dan menganggap realitas media tak beda dengan realitas nyata (prespektif kultivasi), perilaku kekerasan pun disahkan dalam kehidupan sehari-hari. Kalau dahulu banyak yang takut melihat pertumpahan darah, dengan adanya gejala desensitisasi kekerasan, maka darah dan kekerasan menjadi hal yang biasa. Anak-anak ramai-ramai menonton pertunjukan kekerasa ini, kadang malah turut berpartisipasi. Seperti itulah kiranya yang terjadi akhir-akhir ini pada masyarakat Indonesia.

Tampaknya, apa yang dikemukakan Baran dan McQuail tentang teori masyarakat massa, tengah berlangsung di Indonesia, dimana masyarakat mudah dipengaruhi, media mempunyai kekuatan yang besar, sedangkan media banyak berperan disfungsional. News judgement banyak ditinggalkan oleh media kita demi mengejar rating dan prestise yang bermuara pada satu tujuan 
"keuntungan". Media tidak lagi bijaksana dan lupa bahwa mereka adalah institusi sosial yang punya tanggung jawab menjaga tatanan sosial, mendidik masyarakat, bukan sekadar memberikan informasi. tetapi tidak mendidik.

Media massa yang paling besar pengaruhnya adalah televisi. Bagaimana solusinya? Semua harus duduk bersama bermusyawarah dengan berbagai pihak. Media penyiaran televisi yang baik, perlu kita wujudkan, hal ini menuntut adanya goodwill dari berbagai pihak.

Pertama adalah pemerintah, selaku pemimpin dan penyelenggara negara. pemerintah berfungsi sebagai pengatur agar roda aktivitas televisi dapat berjalan sesuai dengan visi dan misi yang diemban. Pemerintah melalui KPI (Komisi Penyiaran Indonesia) bertindak sebagai polisi yang mengatur dan mengawasi materi siaran televisi. Jika KPI melihat ada hal yang perlu diperbaiki, maka KPI berhak untuk memberikan teguran kepada pihak pengelola televisi agar memperbaiki materi siarannya. Fungsi pemerintah sebagai pengawas dan pengatur dalam penyiaran televisi, masih perlu ditingkatkan lagi.

Pihak penyelenggara televisi adalah pihak kedua yang turut berperan dalam membangun siaran televisi yang mendidik. Penyelenggara televisi (pemilik, pekerja, pihak production house, aktor, dan aktris) harus memiliki kesadaran yang penuh dan berkomitmen untuk menyelenggarakan siaran yang bermutu dan mendidik. Masalahnya, komitmen ini belum terwujud, karena televisi yang masih berorientasi pada bisnis (keuntungan). Dengan asas ini, pihak penyelenggara televisi lebih mementingkan tayangan yang digemari dan punya rating tinggi, walaupun pada kenyataannya tayangan tersebut miskin dengan nilai-nilai yang mendidik.

Pihak masyarakat adalah pihak ketiga dan yang turut berperan. Menurut pandangan penulis, pihak inilah yang paling mungkin untuk meniadakan kekerasan dalam tayangan televisi. Masyarakat harus bertindak kritis dalam menonton. Dengan kata lain, masyarakat perlu mendapat informasi mengenai dampak positif dan dampak negatif dari televisi. Jika mereka memiliki pengetahuan ini, diharapkan masyarakat dapat bersikap bijak dalam menghadapi televisi atau "melek media". Masyarakat diharapkan dapat memilah-milah mana tayangan yang perlu dan mana yang tidak.

Selama ini, masyarakat mungkin menganggap bahwa kehadiran media televisi adalah baik. Mereka kurang memahami bahwa televisi hadir dengan seperangkat nilai yang ditawarkannya. Apabila kita tidak kritis dan menyadarinya, secara perlahan seperangkat nilai tersebut akan memengaruhi pikiran dan tindakannya. Oleh sebab itu masyarakat harus cerdas dalam menghadapi televisi. Dan mari kita singkirkan kekerasan dalam menjalani kehidupan.

\section{Daftar Pustaka}

\section{A. Buku}

Ardianto, Elvinaro, dkk. 2007. Komunikasi Massa. Bandung: Simbiosa Rekatama Media.

Baksin, Askurifai. 2006. Jurnalistik Televisi, Teori dan Praktik, Bandung: Simbiosa Rekatama Media.

Effendy, Uchjana, Onong. 1992. Ilmu Komunikasi, Teori dan Praktek. Bandung: Rosdakarya.

Griffin, Emory A. 2004. A First Look At Communication Theory. New York: McGraw-Hill.

Infante, Dominic A, Andrew S. Rancer \& Deanna F. Womack. 2003. Building Communication Theory. Long Grove: Waveland Press.

Littlejohn, Stephen W. 1996., Theories of Human Communication, New York Wadsworth,

Mc Quail, Denis. 1987. Teori Komunikasi Massa Edisi Kedua. Jakarta: Erlangga.

Nurudin. 2004. Komunikasi Massa. Malang: Cespur.

Tankard, James W \& Severin Werner J, Teori Komunikasi,Sejarah, Metode, dan Terapan di Dalam Media Massa, Edisi Kelima. Jakarta: Prenada Media. 


\section{B. Sumber Lain}

www.aber.uk/media/documents/short/cultiv.html, Cultivation Theory Week Eleven Lecture 24, cultivation theory by George Gerbner.

www.asudayton/edu/com/faculty/kenny/ cultivation.html, George Gerbner Cultivation Theory.

http://www.harian-global.com/ news.php?item.25326.10

Hestin, Efek Media Violence, Jakarta, 2005. retrieved on 20 Oct $2007 \mathrm{http}: / / \mathrm{jurnal} . \mathrm{bl} . \mathrm{ac} . \mathrm{id} / \mathrm{wp}$ content/uploads/2007/01/BLCOMv2-n1-artikel5-januari2007.pdf
Santi Indra Astuti, Kekerasan Kriminalitas di Televisi, Bandung, 2005. http:// www.pikiran-rakyat.com/cetak/0204/07/ $\underline{0801 .}$

Henry Subiakto, Kekerasan di TV dan Aturan KPI, Jakarta, 2004. http:// www.kompas.com/kompas-cetak/0406/ $\underline{\text { 04/opini/1060114.htm }}$

Mazdalifah, Belajar Kekerasan dari Televisi, Medan, 2007. http://www.harianglobal.com/news.php?item.25326.10 
